\author{
(C) А. В. Котельбан \\ Вднзу «Буковинський державний медичний університет», м. Чернівці
}

\title{
Оцінка ефективності лікування хронічного катарального гінгівіту в дітей за умов цукрового діабету
}

\begin{abstract}
Резюме. У дітей і підлітків від 30 до 80 \% випадків діагностують хронічний катаральний гінгівіт. За умов відсутності надання своєчасної чи недостатньої лікувально-профілактичної допомоги можливий розвиток генералізованого пародонтиту. Важливим завданням є своєчасно виявити та патогенетично обгрунтувати методи лікування гінгівіту, його хронічних форм, особливо на тлі супутніх соматичних захворювань.

Мета дослідження - оцінити в клінічних умовах ефективність застосування антисептика, пробіотика та імуномодулятора у комплексі лікування хронічного катарального гінгівіту в дітей, хворих на цукровий діабет 1 типу.

Матеріали і методи. Проведено обстеження та лікування 54 дітей віком 12 років, хворих на хронічний катаральний гінгівіт, за умов цукрового діабету 1 типу. В комплексі лікування застосовано антисептик «Декасан», пробіотик «БіоГая ПроДентіс» та імуностимулятор «Імупрет».

Результати досліджень та їх обговорення. У 24 дітей (80,00 \%) основної групи після проведеного лікування удосконаленим методом спостерігалася повна ліквідація запального процесу, в 6 дітей (20,00 \%) виявлено поліпшення стану тканин пародонта. Відмічалося покращення рівня гігієни ротової порожнини у дітей та значне зниження індексів PMA та CPITN, проби Шиллера-Писарєва. Через 3 та 6 місяців після лікування була позитивна динаміка стану тканин пародонта.

Висновки. Аналіз отриманих клінічних даних відображає позитивну динаміку зміни показників стану тканин пародонта в дітей, хворих на хронічний катаральний гінгівіт, на тлі цукрового діабету, що підтверджує високу ефективність запропонованого нами лікувально-профілактичного комплексу.
\end{abstract}

Ключові слова: діти; гінгівіт; цукровий діабет; препарати «Декасан»; «БіоГая ПроДентіс»; «Імупрет».

\section{(C)А. В. Котельбан}

ВГУзУ «Буковинский государственный медицинский университет», г. Черновцы

\section{Оценка эффективности лечения хронического катарального гингивита в детей при сахарном диабете}

Резюме. У детей и подростков от 30 до 80 \% случаев диагностируют хронический катаральный гингивит. При отсутствии оказания своевременной или недостаточной лечебно-профилактической помощи возможно развитие генерализованного пародонтита. Важной задачей является своевременно выявить и патогенетически обосновать методы лечения гингивита, его хронических форм, особенно на фоне сопутствующих соматических заболеваний.

Цель исследования - оценить в клинических условиях эффективность применения антисептика, пробиотика и иммуномодулятора в комплексе лечения хронического катарального гингивита у детей, больных сахарным диабетом 1 типа.

Материалы и методы. Проведено обследование и лечение 54 детей в возрасте 12 лет, больных хроническим катаральным гингивитом, на фоне сахарного диабета 1 типа. В комплексе лечения применен антисептик «Декасан», пробиотик «БиоГая ПроДентис» и иммуностимулятор «Имупрет».

Результаты исследований и их обсуждение. В 24 детей $(80,00$ \%) основной группы после проведенного лечения усовершенствованным методом наблюдалась полная ликвидация воспалительного процесса, в 6 детей (20,00 \%) выявлено улучшение состояния тканей пародонта. Отмечалось улучшение уровня гигиены полости рта у детей и значительное снижение индексов PMA и CPITN, пробы Шиллера-Писарева. Через 3 и 6 месяцев после лечения наблюдалась положительная динамика состояния тканей пародонта.

Выводы. Анализ полученных клинических данных отражает положительную динамику изменения показателей состояния тканей пародонта у детей, больных хроническим катаральным гингивитом, на фоне сахарного диабета, подтверждает высокую эффективность предложенного нами лечебнопрофилактического комплекса.

ключевые слова: дети; гингивит; сахарный диабет; препараты «Декасан»; «БиоГая ПроДентис»; «Имупрет». 


\title{
CA. V. Kotelban
}

Bukovynian State Medical University

\section{Evaluation the effectiveness of the treatment chronic catarrhal gingivitis in children with diabetes mellitus}

\begin{abstract}
Summary. Chronic catarrhal gingivitis is diagnosed in 30 to $80 \%$ of children and adolescents. Generalized periodontitis may develop in the absence or insufficient provision of timely treatment and preventive care. An important task is to promptly identify and substantiate pathogenetic treatment of gingivitis and its chronic form, especially given the concomitant somatic diseases.

The aim of the study - to evaluate the clinical efficacy of antiseptic conditions, probiotics and immunomodulators in complex treatment of chronic catarrhal gingivitis in children with diabetes type I.

Materials and Methods. We examined and treated 54 children, aged 12 years, with chronic catarrhal gingivitis and diabetes type I. The complex of treatment included antiseptic «Dekasan», probiotic «BioGaia ProDentis» and immunostimulant «Imupret.»

Results and Discussion. In 24 children (80.00\%) of the main group completed elimination of inflammation after improved treatment, in 6 children $(20.00 \%)$ revealed improvement in the periodontal tissues. There was marked improvement in oral hygiene in children and significant reducted PMA and CPITN indexes, PisarevShyllyer test. After 3 and 6 months after treatment, there was a positive dynamics of periodontal tissues.

Conclusions. Analysis of the clinical examinations reflects the positive dynamics of indicators of periodontal tissues in children with chronic catarrhal gingivitis against diabetes, which confirms the high efficiency of our proposed health care industry.
\end{abstract}

Key words: children; gingivitis; diabetes; «Dekasan»; «BioGaia ProDentis»; «Imupret».

Вступ. Серед дитячого та дорослого населення спостерігається значне зростання рівня стоматологічної захворюваності. За частотою та поширеністю друге місце після карієсу займають захворювання тканин пародонта. Найчастіше в дітей і підлітків діагностують хронічний катаральний гінгівіт (ХКГ), на частку якого припадає від 30 до 80 \% випадків [8].

Значний вплив на розвиток і перебіг ХКГ має соматична патологія, зокрема захворювання ендокринної системи [5, 6, 9].

Цукровий діабет (ЦД) є найнебезпечнішим серед ендокринопатій [3, 4]. Він посідає четверте місце в структурі усіх хвороб ендокринної системи серед дитячого населення в Україні й найчастіше стає причиною розвитку тяжких хронічних ушкоджень органів та систем. За даними Н. Б. Зелінської (2015), в Україні зареєстровано близько 8 тис. дітей, хворих на цукровий діабет. У дітей та підлітків частіше зустрічається найтяжча його форма - інсулінозалежний цукровий діабет [4].

Головним чинником розвитку і прогресування діабетичних змін у тканинах організму, зокрема і пародонта, є хронічна гіперглікемія, що запускає цілий каскад патофізіологічних, біохімічних та імунологічних реакцій $[1,5,6$, 9]. Найхарактернішими є ушкодження судин- ної стінки артеріол, венул, капілярів у васкуляризованих тканинах, у тому числі й тканинах пародонта [1, 3, 5-8].

За умов відсутності надання своєчасної чи недостатньої лікувально-профілактичної допомоги можливий розвиток генералізованого пародонтиту. Саме тому найважливішим завданням є своєчасно виявити та патогенетично обгрунтувати методи лікування гінгівіту, його хронічних форм, особливо на тлі супутніх соматичних захворювань.

Мета дослідження - оцінити в клінічних умовах ефективність застосування антисептика, пробіотика та імуномодулятора в комплексі лікування ХКГ у дітей, хворих на цукровий діабет 1 типу.

Матеріали і методи. Для вирішення поставленої мети було проведено обстеження та лікування 54 дітей віком 12 років, хворих на хронічний катаральний гінгівіт, за умов цукрового діабету 1 типу (29 хлопців та 25 дівчат), які перебували на стаціонарному лікуванні в ендокринологічному відділенні ОКУ «Обласна дитяча клінічна лікарня» м. Чернівці.

До першої групи увійшло 30 дітей (17 хлопців та 13 дівчат), яким проводили лікування ХКГ, що включало професійну гігієну ротової порожнини, полоскання ротової порожнини 
антисептичним розчином «Декасан» $0,02 \%$ двічі на день до клінічного ефекту зникнення ознак запалення; розжовування 1 пігулки пробіотичної дії «БіоГая ПроДентіс» 2 рази на день впродовж 2 тижнів; призначення перорально імуностимулятора «Імупрет» за схемою: 25 крапель 5-6 разів на добу впродовж 2 тижнів. Дітям другої групи порівняння (24 дитини: 12 хлопців та 12 дівчат) проводили лікування згідно з протоколами МОЗ України щодо надання медичної допомоги за спеціальністю «Дитяча терапевтична стоматологія».

Оцінку ефективності лікування ХКГ у дітей ми виконали до лікування, після його завершення, через 3 та 6 місяців.

Стоматологічне обстеження дітей здійснювали за загальноприйнятими методами. Гігієнічний стан ротової порожнини визначали за індексом гігієни OIH-S (Гріна-Вермільйона, 1964), оцінку стану тканин пародонта оцінювали за індексами PMA та CPITN, пробою Шиллера-Писарєва.

Статистичну обробку даних виконали методами варіаційної статистики з використанням критерію Стьюдента.
Результати досліджень та ї обговорення. Клінічний огляд дітей основної групи відразу після проведеного лікування показав, що у 24 (80,00 \%) спостерігалася повна ліквідація запального процесу, в 6 (20,00 \%) виявлено поліпшення стану тканин пародонта. У порівняльній групі в 11 дітей $(45,83 \%)$ була повна ліквідація запального процесу та в 13 (54,17 \%) спостерігали поліпшення стану тканин пародонта.

У динаміці проведеного лікування ХКГ середні показники пародонтальних індексів у дітей першої та другої груп суттєво відрізнялися, що представлено у таблиці.

Із даних таблиці видно, що до початку лікування ХКГ у дітей пародонтальні індекси були приблизно однакового значення, після проведеного першого курсу лікування виявлено покращення пародонтальних індексів в обох групах дослідження відразу після проведеної санації. Однак у дітей основної групи, в яких ми застосовували запропонований лікувально-профілактичний комплекс, зміни індексних оцінок мали більш виражений позитивний характер.

Таблищя. Стан тканин пародонта та гігієни ротової порожнини в дітей груп спостереження у динаміці лікування

\begin{tabular}{|c|c|c|c|c|c|c|}
\hline Показник & Група & дЛ & ПЛ & ЗМПЛ & 6МПЛ & $\mathrm{p}$ \\
\hline \multirow{2}{*}{$\begin{array}{l}\text { Індекс Гріна- } \\
\text { Вермільйона, } \\
\text { бали }\end{array}$} & $\begin{array}{l}\text { перша, } \\
\mathrm{n}=30\end{array}$ & $1,04 \pm 0,11$ & $0,45 \pm 0,03^{*}$ & $0,66 \pm 0,04^{*}$ & $0,69 \pm 0,04^{*}$ & $\begin{array}{l}\mathrm{p}_{1}<0,01 \\
\mathrm{p}_{2}<0,01 \\
\mathrm{p}_{3}<0,01 \\
\mathrm{p}_{4}<0,01 \\
\mathrm{p}_{5}<0,01 \\
\mathrm{p}_{6}<0,01\end{array}$ \\
\hline & $\begin{array}{l}\text { друга, } \\
\mathrm{n}=24\end{array}$ & $1,15 \pm 0,10$ & $0,69 \pm 0,04^{*}$ & $0,72 \pm 0,04^{*}$ & $0,78 \pm 0,06^{*}$ & $\begin{array}{l}\mathrm{p}_{1}<0,01 \\
\mathrm{p}_{2}>0,05 \\
\mathrm{p}_{3}>0,05 \\
\mathrm{p}_{4}>0,05 \\
\mathrm{p}_{5}>0,05 \\
\mathrm{p}_{6}>0,05\end{array}$ \\
\hline \multirow{2}{*}{$\begin{array}{l}\text { Індекс гінгівіту } \\
\text { (РМА), \% }\end{array}$} & $\begin{array}{l}\text { перша, } \\
\mathrm{n}=30\end{array}$ & $28,32 \pm 3,09$ & $5,02 \pm 1,87^{*}$ & $11,30 \pm 2,25^{*}$ & $14,37 \pm 2,54^{*}$ & $\begin{array}{l}\mathrm{p}_{1}<0,01 \\
\mathrm{p}_{2}<0,01 \\
\mathrm{p}_{3}<0,01 \\
\mathrm{p}_{4}<0,01 \\
\mathrm{p}_{5}<0,01 \\
\mathrm{p}_{6}<0,01\end{array}$ \\
\hline & $\begin{array}{l}\text { друга, } \\
\mathrm{n}=24\end{array}$ & $29,34 \pm 3,17$ & $11,29 \pm 2,57^{*}$ & $19,92 \pm 2,16^{*}$ & $23,11 \pm 2,57^{*}$ & $\begin{array}{l}\mathrm{p}_{1}<0,01 \\
\mathrm{p}_{2}<0,01 \\
\mathrm{p}_{3}<0,01 \\
\mathrm{p}_{4}<0,01 \\
\mathrm{p}_{5}<0,01 \\
\mathrm{p}_{6}>0,05\end{array}$ \\
\hline
\end{tabular}


Продовження табл.

\begin{tabular}{|c|c|c|c|c|c|c|}
\hline Показник & Група & дЛ & ПЛ & ЗМПЛ & 6МПЛ & $\mathrm{p}$ \\
\hline \multirow{2}{*}{$\begin{array}{l}\text { Проба Шиллера- } \\
\text { Писарєва, бали }\end{array}$} & $\begin{array}{l}\text { перша, } \\
\mathrm{n}=30\end{array}$ & $1,68 \pm 0,19$ & $0,51 \pm 0,10^{*}$ & $0,81 \pm 0,10^{*}$ & $1,03 \pm 0,18^{*}$ & $\begin{array}{l}\mathrm{p}_{1}<0,01 \\
\mathrm{p}_{2}<0,01 \\
\mathrm{p}_{3}<0,01 \\
\mathrm{p}_{4}<0,05 \\
\mathrm{p}_{5}<0,05 \\
\mathrm{p}_{6}<0,05\end{array}$ \\
\hline & $\begin{array}{l}\text { друга, } \\
\mathrm{n}=24\end{array}$ & $1,92 \pm 0,31$ & $0,85 \pm 0,05^{*}$ & $1,18 \pm 0,14^{*}$ & $1,43 \pm 0,18^{*}$ & $\begin{array}{l}\mathrm{p}_{1}<0,01 \\
\mathrm{p}_{2}>0,05 \\
\mathrm{p}_{3}>0,05 \\
\mathrm{p}_{4}>0,05 \\
\mathrm{p}_{5}<0,05 \\
\mathrm{p}_{6}<0,05\end{array}$ \\
\hline \multirow{2}{*}{$\begin{array}{l}\text { Кровоточивість, } \\
\text { секстанти }\end{array}$} & $\begin{array}{l}\text { перша, } \\
\mathrm{n}=30\end{array}$ & $4,11 \pm 0,28$ & $0,27 \pm 0,08^{*}$ & $0,87 \pm 0,16^{*}$ & $1,13 \pm 0,21^{*}$ & $\begin{array}{l}\mathrm{p}_{1}<0,01 \\
\mathrm{p}_{2}<0,01 \\
\mathrm{p}_{3}<0,01 \\
\mathrm{p}_{4}<0,01 \\
\mathrm{p}_{5}<0,01 \\
\mathrm{p}_{6}<0,01\end{array}$ \\
\hline & $\begin{array}{l}\text { друга, } \\
\mathrm{n}=24\end{array}$ & $4,71 \pm 0,29$ & $0,92 \pm 0,20^{*}$ & $1,62 \pm 0,13^{*}$ & $1,79 \pm 0,17^{*}$ & $\begin{array}{l}\mathrm{p}_{1}<0,01 \\
\mathrm{p}_{2}<0,05 \\
\mathrm{p}_{3}<0,01 \\
\mathrm{p}_{4}<0,01 \\
\mathrm{p}_{5}<0,01 \\
\mathrm{p}_{6}>0,05\end{array}$ \\
\hline \multirow{2}{*}{$\begin{array}{l}\text { Зубний камінь, } \\
\text { секстанти }\end{array}$} & $\begin{array}{l}\text { перша, } \\
\mathrm{n}=30\end{array}$ & $1,11 \pm 0,29$ & 0 & $0,37 \pm 0,14^{*}$ & $0,37 \pm 0,14^{*}$ & $\begin{array}{l}\mathrm{p}_{1}>0,05 \\
\mathrm{p}_{2}>0,05 \\
\mathrm{p}_{3}>0,05 \\
\mathrm{p}_{4}<0,01 \\
\mathrm{p}_{5}<0,01 \\
\mathrm{p}_{6}<0,01\end{array}$ \\
\hline & $\begin{array}{l}\text { друга, } \\
\mathrm{n}=24\end{array}$ & $2,04 \pm 0,34$ & 0 & $0,71 \pm 0,17^{*}$ & $0,75 \pm 0,14^{*}$ & $\begin{array}{l}\mathrm{p}_{1}<0,01 \\
\mathrm{p}_{2}>0,05 \\
\mathrm{p}_{3}>0,05 \\
\mathrm{p}_{4}>0,05 \\
\mathrm{p}_{5}>0,05 \\
\mathrm{p}_{6}>0,05\end{array}$ \\
\hline
\end{tabular}

Примітки: 1) ДЛ - до лікування, ПЛ - після лікування, 3МПЛ - 3 місяці після лікування, 6МПЛ - 6 місяців після лікування;

2) p $_{1}$ - вірогідність різниці між показниками першої або другої групи до та після лікування;

3) $\mathrm{p}_{2}$ - вірогідність різниці між показниками першої або другої групи до та через 3 місяці після лікування;

4) $\mathrm{p}_{3}$ - вірогідність різниці між показниками першої або другої групи до та через 6 місяців після лікування;

5) $\mathrm{p}_{4}$ - вірогідність різниці між показниками першої або другої групи після лікування та через 3 місяці після лікування;

6) $\mathrm{p}_{5}$-вірогідність різниці між показниками першої або другої групи після лікування та через 6 місяців після лікування;

7) $\mathrm{p}_{6}$ - вірогідність різниці між показниками першої або другої групи через 3 місяці після лікування та через

6 місяців після лікування;

8) * - вірогідність різниці між показниками першої та другої груп у динаміці лікування.

Отже, після лікування у дітей першої групи значення РМА становило 5,02 \% проти 11,29 \% $(\mathrm{p}<0,01)$ у дітей другої групи. Через 3 та 6 місяців після лікування спостерігали позитивну динаміку стану тканин пародонта.
Середнє значення індексу Гріна-Вермільйона в дітей основної групи і групи порівняння відразу після проведеного лікування становило, відповідно, $(0,45 \pm 0,03)$ та $(0,69 \pm 0,04)$ бала, що вказує на добру гігієну ротової порожнини. 
Через 3 місяці після проведеної санації у дітей першої групи показник становив 0,66 0,04 , а через 6 місяців - 0,69 $\pm 0,04$.

Проба Шиллера-Писарєва (йодне число Свракова) після проведеного лікування була позитивна в усіх дітей основної та порівняльної груп. Ці дані відображають наявність запального процесу в тканинах пародонта та прихований перебіг ХКГ у клінічно інтактних тканинах пародонта в обстежених дітей за умов цукрового діабету. В 3 рази зменшився ступінь запального процесу в тканинах пародонта після проведеного лікування в дітей першої та в 2 рази у дітей другої груп, через 3 та 6 місяців - відповідно в 2 і 1,5 та 1,6 і 1,3 раза.

Оцінюючи стан тканин пародонта за індексом CPITN, слід відзначити, що значна кількість дітей обох дослідних груп мала секстанти з кровоточивістю та зубним каменем.

Секстанти з кровоточивістю ясен були відсутні в 24 дітей (80,00 \%) основної групи після проведеного лікування, тоді як у дітей групи порівняння - в 11 обстежених (45,83 \%). Через 3 місяці після проведених лікувально-профі-

\section{Список літератури}

1. Бабіна О. О. Особливості клініки і лікування пародонтального синдрому у дітей, хворих на цукровий діабет : автореф. дис. на здобуття наук. ступеня канд. мед. наук : спец. 14.01.22 «Стоматологія» / О. О. Бабіна. - Полтава, 2000. - 18 с.

2. Взаємозв'язок запальних захворювань тканин пародонта та соматичних захворювань у дітей: огляд літератури / [Л. О. Хоменко, Ю. В. Марушко, О. Д. Московенко, О. В. Дуда] // Новини стоматології. 2015. - № 2. - С. 90-94.

3. Дедов И. И. Сахарный диабет: развитие технологий в диагностике, лечении и профилактике / И. И. Дедов // Сахарный диабет. - 2010. - № 3. - С. 6-14. 4. Зелінська Н. Б. Стан надання медичної допомоги дітям 3 ендокринною патологією в Україні у 2014 році / Н. Б. Зелінська, Н. Г. Руденко // Український журнал дитячої ендокринології. - 2015. - № 2. C. 5-13.

5. Карачевська К. О. Клінічні та морфофункціональні особливості ураження тканин пародонта у дітей, хворих на цукровий діабет I типу, їх лікування та профілактика : автореф. дис. на здобуття наук. сту-

\section{REFERENCES}

1. Babina, O.O. (2000). Osoblyvosti kliniky i likuvannia parodontalnoho syndromu u ditey, khvorykh na tsukrovyi diabet. [Clinic and treatment of periodontal syndrome in children with diabetes]. Candidate's thesis. Poltava [in Ukrainian]

2. Khomenko, L.O., Marushko, Yu.V., Moskovenko, O.D., Duda O.V. Vzaiemozviazok zapalnykh zahvoriuvan лактичних заходів виявлено у 4,72 раза менше секстантів із кровоточивістю в дітей першої та 2,94 раза в дітей другої груп. Через 6 місяців кількість секстантів змінилася 3 4,11 на 1,13 після проведеного лікування в дітей першої групи.

У дітей першої групи кількість секстантів із зубним каменем зникла після проведеного лікування, а через 3 та 6 місяців після лікування кількість секстантів із зубним каменем вірогідно не відрізнялася.

Поряд із позитивною динамікою стану тканин пародонта у дітей за умов цукрового діабету, яким запропонували удосконалений метод лікування, відмічали поліпшення рівня гігієни ротової порожнини.

Висновки. Позитивна динаміка зміни клінічних показників стану тканин пародонта у дітей, хворих на ХКГ, на тлі ЦД відображають високу ефективність запропонованого нами лікувально-профілактичного комплексу із застосуванням антисептика "Декасан», пробіотика «БіоГая ПроДентіс» та імуностимулятора «Імупрет».

пеня канд. мед. наук : спец. 14.01.22 «Стоматологія» / К. О. Карачевська. - К., 2007. - 18 с.

6. Крижалко О. В. Особливості клініки, профілактики та лікування захворювань тканин пародонта у дітей, хворих на цукровий діабет : автореф. дис. на здобуття наук. ступеня канд. мед. наук : спец. 14.01.22 «Стоматологія» / О. В. Крижалко. - К., 2001. -18 c.

7. Распрастраненность и интенсивность стоматологической патологии у больных сахарным диабетом / И. К. Новицкая, Т. П. Терешина, Т. И. Димчева и др. // Інновації в стоматології. - № 1. - 2014. - С. 11-13.

8. Савичук Н. О. Коррекция микроэкологических нарушений в составе лечебно-профилактических мероприятий у детей с хроническим генерализованным катаральным гингивитом / Н. О. Савичук / Дельта Дайджест. - № 1. - 2015. - С. 5-8.

9. Скиба А. В. Патогенетические аспекты профилактики и лечения стоматологических заболеваний при сахарном диабете : автореф. дис. на здобуття наук. ступеня докт. мед. наук : спец. 14.01.22 «Стоматологія» / А. В. Скиба. - Одесса, 2016. - 286 с.

tkanyn parodonta ta somatychnykh zakhvoriuvan $\mathrm{u}$ ditey. Ohliad literatury [The relationship of inflammatory diseases of periodontal and systemic diseases in children. Literature review]. Novyny stomatolohii - News of Dentistry, 2, 90-94 [in Ukrainian]. 3. Dedov I.I. (2010). Sakharnyi diabet: razvitie tehnologiy $\mathrm{v}$ diagnostike, lechenii i profilaktike [Diabetes: the 


\section{Дитяча стоматологія}

development of technologies in the diagnosis, treatment and prevention]. Sakharnyi diabet - Diabetes Mellitus, 3, 6-14.

4. Zelinska, N.B., \& Rudenko, N.G. Stan nadannia medychnoi dopomohy ditiam $\mathrm{z}$ endokrynnoiu patolohiieiu v Ukraini u 2014 rotsi [Condition of children care with endocrine pathology in Ukraine in 2014]. Ukrainskyi zhurnal dytiachoi endokrynolohii - Ukrainian Journal of Children's Endocrinology, 2, 5-13 [in Ukrainian].

5. Karachevska, K.O. (2007). Klinichni ta morfofunktsionalni osoblyvosti urazhennia tkanyn parodonta $\mathrm{u}$ ditey, khvorykh na tsukrovyi diabet I typu, yikh likuvannia ta profilaktyka. [Clinical and morphological features of lesions of periodontal tissues in children with diabetes mellitus, treatment and prevention]. Candidate's thesis. Kyiv [in Ukrainian].

6. Kryzhalko, O.V. (2001). Osoblyvosti kliniky, profilaktyky ta likuvannia zakhvoriuvan tkanyn parodonta u ditei, khvorykh na tsukrovyi diabet [Clinic, prevention and treatment of periodontal tissues in children with diabetes]. Candidate's thesis. Kyiv [in Ukrainian].
7. Novitskaya, Y.K., Tereshyna T.P., \& Dimcheva, T.I. (2014). Rasprastranennost i intensivnost stomatologicheskoy patologii $\mathrm{u}$ bolnykh sakharnym diabetom [Grafting and the intensity of dental disease in patients with diabetes]. Innovatsii $v$ stomatolohii-Innovations in Dentistry, 1, 11-13 [in Russian].

8. Savychuk, N.O. (2015). Korrektsiya mikroekologicheskih narusheniy v sostave lechebno-profilakticheskikh meropriyatiy $\mathrm{u}$ detey $\mathrm{s}$ hronicheskim generalizovannym kataralnym gingivitom [Correction of microecological violations as a part of therapeutic and preventive measures in children with chronic generalized catarrhal gingivitis]. Delta Daydzhest - Delta Digest, 1, 5-8 [in Russian].

9. Skyba, A.V. Patogenetycheskie aspekty profilaktiky i lecheniya stomatologicheskikh zabolevaniy pry sakharnom diabete. [Pathogenetic aspects of prevention and treatment of dental disease in diabetes]. Candidate's thesis. Odessa [in Russian].

Отримано 02.02.17 